\title{
FEASIBILITY STUDY OF THE RECEPTION FACILITY DEVELOPMENT OF TANJUNG PERAK BRANCH SURABAYA
}

\author{
Achmad Djamaludin ${ }^{1}$, Benny Sukandari ${ }^{1}$, Eko Krisdiono ${ }^{1}$, Ali Mashudi ${ }^{1}$ \\ ${ }^{1}$ Indonesian Naval Technology College, \\ STTAL-Bumimoro-Morokrembangan, Surabaya 60187, Indonesia
}

\section{ABSTRACT}

Presently, the rapidly increasing population growth has been shown to create the growing needs of sea transportation services, both for freight and passengers. The augmentation of sea transportation fleets causes the ever-increasing number of all types of ships and the vessel traffic congestion in many connected sailing lanes. The development of sea transportation media significantly affects the potency of sea pollution. Therefore, it requires an analysis of the development feasibility of the Reception Facility in Tanjung Perak Port Surabaya.

The first analysis is by doing the evaluation of investment feasibility based on the law, market, technical and financial aspects. After that, the measurement is done by using the methods of Net Present Value (NPV), Payback Period (PP), Internal Rate of Return (IRR), Average Rate of Return (ARR), Profitability Index (PI) and investment risk analysis.

In this research, the gained NPV is about Rp. 431.257.167, PP value about 8 years 9 months 26 days, IRR 22,695\%, ARR 30,32\%, PI about 1,39, so the infrastructure investment program of Reception Facility in Tanjung Perak Port Surabaya is feasible to be carried out.

Keywords: Feasibility Study, NPV, PP, IRR, ARR, PI, Investment Risk.

\section{INTRODUCTION.}

The increasingly rapid population growth today has an impact on the increasing needs of the marine transportation fleet, both for passengers and goods. The increase in the marine transportation fleet has resulted in the increasing number of ships and the density of ship traffic in various shipping lanes. The development of sea transportation media has a great impact on the potential of marine pollution, one of which is caused by ships. Marine pollution caused by ships, including disposal of wastewater and water treatment, sewage water, ballast water, marine debris (garbage from the ship), dumping waste; and maritime accidents, such as oil spills, shipwrecks, and others. Marine pollution that occurs will cause harm to the ecosystem of the marine environment, including humans who are part of the ecosystem. In other words, sea pollution not only damages the habitat of marine organisms and their biological and physiological processes but can endanger human health and life. This is because food originating from the sea has accumulated by pollutants.

The sea must be free from pollution because, in addition to being a source of food, the sea also has various types of resources that can be used to meet the needs of life and improve human welfare. Until now, pollution control activities by ships have continued to be pursued by improving ship operational procedures. In addition to improving vessel operational procedures, pollution control can be carried out by providing alternative means of shelter and processing of ship waste in ports (port reception facilities). 
The existence of port reception facilities can be used by operators and/or ship owners for activities to control ship waste. The International Maritime Organization (IMO) states that port reception facilities are various facilities at a seaport to receive ship waste that usually contains oil, toxic materials, other liquid wastes, and garbage when the ship rests (Saut Gurning; 2001).

With the increase in the number of vessels leaning each year, this port requires port reception facilities to store waste from lean vessels to prevent pollution in the Surabaya and surrounding seas.

Based on the existing problems, this research is intended to find out the extent to which the benefits obtained when carried out are the Construction of the Reception Facility of Tanjung Perak Port, Surabaya.

\section{MATERIALS/METHODOLOGY.}

\subsection{Formulation of the problem.}

Based on the background stated above, the formulation of the problem to be solved in this study is "Is the Development of Reception Facility Management in Tanjung Perak Branch Port Surabaya feasible to be implemented in terms of legal aspects, market aspects, technical aspects, and financial aspects?".

\subsection{Research purposes.}

The purpose of this research is to analyze the feasibility of developing the management of the Reception Facility of the Tanjung Perak branch port of Surabaya, especially in terms of legal aspects, market aspects, technical aspects, and financial aspects.

\subsection{Restricting the problem.}

The extent of the problems involved in implementing this feasibility analysis, it is necessary to limit the problems in this research activity, among others:

1. This analysis is carried out only in the Construction of the Reception Facility Management of Tanjung Perak Branch Port in Surabaya.

2. In this writing does not discuss the existence of a leadership policy outside the applicable regulations.

3. In this study does not discuss in detail the legal aspects and scheduling of development Management of the Reception Facility.

4. In this study does not discuss in detail the process of shelter and processing of ship waste.

5. This study does not discuss social aspects.

\subsection{Understanding the project.}

The understanding of the project is activities that can be planned, coordinated and carried out in a form of unity by using resources to obtain benefits or benefits in a timely and appropriate manner (Suad Husnan and Suwarsono, 1994, 4).

From the definition above, it can be concluded that an activity or a project is carried out where spending money or which can be called investment with the hope of getting a future result in the form of a profit and the activity can be planned, financed and can be implemented as a business unit, so that a project always has a starting point and an end point, both in terms of costs and the results to be measured.

\subsection{Feasibility study.}

Feasibility studies can be interpreted as research on whether or not a project can be carried out successfully. This understanding of success may be interpreted 
somewhat differently. (Suad Husnan and Suwarsono, 1994, third edition) Feasibility studies if done professionally will play an important role in the investment decision making the process.

Investment projects generally require funds that have little effect on the company over a long period of time, therefore a project feasibility study is needed so that the invested funds are not wasted, so the purpose of the project feasibility study is to avoid too much investment for a project activity that turns out to be unprofitable.

Many causes a project to be unprofitable, for example, due to planning errors, errors in estimating available markets, errors in the estimates of appropriate technology used, errors in estimates of the continuity of raw materials, errors in estimates of the number of workers with the availability of existing workforce. Other reasons can come from the implementation of uncontrolled projects so that the cost of building the project becomes swollen or the solution is delayed.

Besides that, it is also caused by changing environmental factors, both economic, social or political environment. It could also be for reasons that are truly unexpected, such as natural disasters at the project site.

Things that need to be known in the feasibility study:

1. The scope of project activities, there needs to be explained or determined, in what areas the project will operate.

2. The way the project activities are carried out, whether the project will be handled alone or submitted to other parties and who will handle it.
3. Evaluation of the aspects that determine the success of the entire project.

4. Facilities needed by the project, the means in question are not only about material and labor needs but also other supporting facilities such as roads and transportation and other supports.

5. Useful consequences or not from the project concerned.

6. The results of the project activities and the costs that must be borne to obtain these results.

7. Planning steps to establish the project along with the schedule of each project activity until the project is running.

Not all projects are analyzed with the same level of intensity, there are several factors that affect project intensity, namely:

1. The number of funds invested, the greater the funds invested, the more in the analysis carried out on the project

2. The level of project uncertainty, if the project is difficult to see how much income it receives, sales, costs that must be incurred, the more careful the analysis is carried out.

3. The complexity of the elements that affect the project.

Parties that need a Feasibility Study:

1. Investors are parties who will invest in the project, where they will pay attention to the business prospects that will be implemented. Where the prospect here is interpreted as the expected level of profit along with the risks - the risks. There is a positive relationship. Between the level of profit and investment risk, the higher the risk the higher the level of profits requested by investors. 
2. Creditors, pay attention to security aspects. They expect interest plus loan installments on time, they also pay attention to cash flow in the loan period, but that does not mean creditors do not pay attention to the project, but their main concern lies in the loan repayment period and subsequently will not be of concern to them.

3. The government expects the project to benefit the national economy in the sense that it can save foreign exchange, increase employment opportunities and others. This benefit is mainly associated with overcoming the problems - problems that are being faced by the country.

Aspects that are influential in the feasibility study

a. Legal Aspects

Explain about several things or factors related to the law concerning the legality of the company and investment. Matters relating to the law include:

1) The business entity used by the company has a legal entity or already has a register number of a business entity issued by the government.

2) The company management activities or processes carried out have followed the laws that apply to companies.

3) The process of business/investment agreements has fulfilled the applicable legal process.

b. Market Aspects

According to Suad Husnan and Suwarsono, 1994, edition 3 page 32, in evaluating market aspects there are things that need to be examined beforehand, namely about the description of the intended market, which includes the market area and method of transportation, identifying potential customers, the product position planned at present, the composition and development of product demand from the past to the present, projections of demand in the future come to the possibility of competition and the role of government in supporting the development of product marketing.

\section{c. Technical aspects}

According to Suad Husnan and Suwarsono, 1992, page 2 edition 96 technical aspects are aspects related to project development technically and operating after the project was built and carried out after research on aspects of the market was agreed to be carried out.

Evaluation of technical analysis includes product descriptions, determining the economic product capacity of the project, processes carried out by raw material inventories, number of workers, use of machinery and tools. Besides that, it also needs to be investigated to submit suggestions about the location of the project and the layout of the plant which is most profitable in terms of various aspects, so that the initial design of the investment cost is included, including the costs of exploitation.

The implementation of the evaluation of technical aspects often cannot provide a standard decision, or in other words, there are still various alternative answers, so it is very important to pay attention to one or several experiences on similar projects that use the same techniques and technologies.

d. Financial Aspects

According to Suad Husnan and Suwarsono, 1994, 3rd edition page 96, the financial aspect discusses how to calculate funding needs, both the need for funds for 
fixed assets, but also for working capital. In addition, there were also discussed sources of funds that could be used to meet the need for these funds.

The need and fixed capital to build industrial projects include funding and procurement of pre-investment activities, fixed assets and other costs related to the project development effort. The included intangible fixed assets are:

1) Land and location development. These costs include the price of land, including the costs of registration, cleaning, land preparation, construction of the nearest road, fencing and so on.

2) Buildings and equipment. This includes buildings for factories, buildings for administration, warehouses, for power plants, security posts, architectural services and so on.

3) Factories and machines. This is the largest component of investment, including the costs of building factories, machine prices, installation costs, transportation costs, spare parts and so on. It is better to separate imported and local machines to include possible exchange rate changes.

4) Transportation and material handling equipment, equipment for research and development, office equipment.

Besides the cost of preinvestment activities and the procurement of fixed assets, there are still several other types of financing that can be considered as fixed capital financing, namely the procurement of technology, trial production costs, and loan interest payments during the project construction period.

\subsection{Net Present Value (NPV).}

This method is used to calculate the difference between the present value of revenues - net cash receipts (both operational and terminal cash flow) in the future. Where to calculate the present value needs to be determined in advance the relevant interest rate.

\subsection{IRR (Internal Rate of Return).}

It is the interest rate which when used to discount the entire cash inflow in the years of operation of the project will produce the same amount of cash as the total investment of the project. Basically, IRR describes the percentage of actual profits generated by the project, the percentage is obtained by trial and error. If the total cash difference is greater than the investment amount, the percentage of interest to be used for discounting is lower than the IRR sought.

\subsection{ARR (Average Rate Of Return).}

This method also does not consider the time value of money. The calculation is based on profits/profits reported in the accounting report or company financial statements, hence it is called the average rate of return.

This method measures how much the average profit rate obtained from an investment. The number used is after-tax profit compared to average investment. Furthermore, the results are compared with the required profit level.

\subsection{PP (Payback Period).}

This payback period is a valuation method that produces a period of time. The intended period is needed to close, the initial 
investment in a project by using the cash flow generated by the project. The basic calculation uses cash flow but is not discounted. So this method ignores the time value of money (Pujawan, N, I, 2004, 11

The general description of the research method in the form of a flow chart is the steps of research in general which can be seen in Figure 3.1

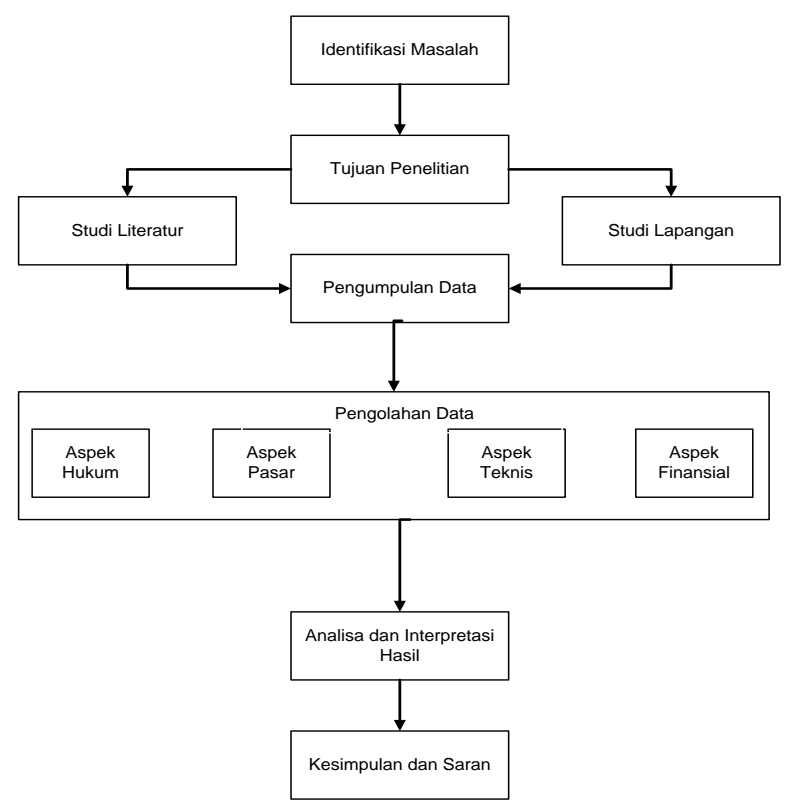

Fig. 1 Research Flow Chart

Identification of problems

The problem in this study is whether the construction of the Tanjung Perak Port Reception Facility Management in Surabaya will be feasible in terms of several aspects and can address ship waste around the Surabaya waters so that the results of this study can be used as input for the PT. Pelindo Indonesia (Persero) Tanjung Perak branch of Surabaya and local government. The purpose of this study is to determine the aspects that influence the feasibility of development management

\section{Data Collection And Processing}

In this chapter, you will present data and processing of information obtained as long as the author collects data. The results of data collection will be grouped into four parts, namely legal aspects, market aspects, technical aspects, and financial aspects. Furthermore, the information will be processed and used as a basis for assessing and analyzing in accordance with systematic problem solving

\section{Legal Aspects}

The port is a place or facility for economic activities that ships use to anchor, boarding passengers and loading and unloading goods so that they have a very important role related to economic activities involving water activities. The mobility of shipping traffic at the Tanjung Perak Port of Surabaya has the consequence of increasing the volume of ship exhaust, including one of which is the discharge of oil-containing vessels around the harbor waters. This situation can potentially damage the marine environment.

Government Regulation Number 21 of 2010 concerning Maritime Environment protection. Chapter IV Article 17 (1) each port operated must fulfill the requirements to prevent pollution from sources at activities in the port including special terminals.

\section{Market Aspects}

In the past analysis it is seen the potential of a project to absorb the market both now and in the future. The plan to sell vessel waste storage services in this analysis is basically only for foreign vessels.

For forecasting the arrival of ships that will come from the data calculation of ship arrival forecasting using the Moving Average method, single Exponential Smoothing and Double Exponential Smoothing forecasting results for the next 10 years as shown in table 4.1.

From the results of the data forecasting both with the Moving Average method, single Expansion Smoothing and Double Expansion Smoothing, get 
that the number of reports on ship arrivals is quite high. Table 4.1 shows that the forecast reports of ship arrivals that took place in the port of Tanjung Perak Surabaya during the period of 2012 to 2021 obtained an average of 846 calls/year.

\section{RESULT AND DISCUSSION.}

\subsection{Project location.}

For the location of the establishment of the Reception, Facility is the Surabaya Tanjung Perak Branch Port, precisely on the patchouli dock on Jl. West Patchouli No. 10 Surabaya so that this location is easily accessible by ships that are in the Port of Surabaya.

\subsection{Depreciation Calculation.}

Capital Investment Depreciation is determined using Straight line depreciation can be calculated by the formula:

$\mathrm{Dt}=(\mathrm{P}-\mathrm{S}) / \mathrm{N}$

The construction facility for the reception facility is $1,095,485,000.00$. And it is estimated that the service life is 10 years with the remaining value of $109,548,500.00$

$\mathrm{P}=$ Rp. 1.095.484.400,00

$\mathrm{S}=\mathrm{Rp} .109 .548 \cdot 440,00$

$\mathrm{N}=10$ Years

$\mathrm{Dt}=(\mathrm{P}-\mathrm{S}) / \mathrm{N}$

$=($ Rp. 1.095.484.400,00 - Rp.

109.548.440,00) / 10

$=$ Rp. $98.593 .596,00$

Investment feasibility analysis is calculated on a profit basis

To find out the investment projection plan, the construction of the Profit Facility on a profit with the assumption that investment from private capital is viewed from the financial aspect so that it can be known to be feasible or not feasible by using capital budgeting techniques.

\subsection{Cash Flow Pattern.}

Assessing an investment based on the estimated cash flow that will be obtained is not easy. For that, it is recommended to use the calculation of the difference between the cash actually obtained minus the cash actually spent. By looking at one of the results of data processing presented in the form of a projection of an income statement, the projection that shows the elements of cash receipts and disbursements over a period of 10 years.

From the cash flow projection, it is seen that there are additional cash inflows in each period, this shows that financial performance continues to increase which means showing the ability to fulfill obligations in terms of installments and interest along with other costs.

\subsection{Capital budgeting technique used Net Present Value (NPV) Method.}

The method of valuation of investment is the calculation is to find the difference between the cash inflows that have been discounted at the minimum interest rate (Cost of Capital) and the value of the investment. If the difference between the two elements is greater than zero (positive), it means that the investment in terms of financial aspects is feasible. However, if what happens is the opposite, namely the difference in value is smaller than the number (negative), then the investment is rejected because in terms of financial aspects it is not feasible to do so.

The process of calculating the Net Present Value (NPV) investment plan for the construction of a reception facility in Tanjung Perak Branch of Surabaya with a cost of capital of $14 \%$ per year as a discount factor 
obtained from the amount of bank loan interest.

The calculation using the Net Present Value (NPV) method is to find the difference between the cash inflow that has been discounted at the cost of the capital level of the reception facility development project in Tanjung Perak Branch Port Surabaya with the investment value.

The calculation results show that NPV is greater than zero or precisely $R p$. $431.258,162$, - for 10 years the projection means that in terms of the financial aspects of the reception facility development project, the Tanjung Perak Branch Port of Surabaya is feasible to be continued.

\subsection{Profitability Index (PI) Method.}

$\mathrm{PI}$ calculation method is used to view or measure the present value for each rupiah invested during $\mathrm{Pl}>1$, then the planned construction of a reception facility for Surabaya Tanjung Perak Branch Port can be implemented, but if the opposite happens when the plan must be rejected. PI which is greater or equal to 1 , means that the NPV is greater or equal to zero (0).

From the calculation in table $4.10, \mathrm{PI}$ is obtained with a value of 1.394 which means it is worth above 1 , so the reception facility development project of Tanjung Perak Branch Port in Surabaya is feasible.

Internal Rate of Return (IRR) Method Internal Rate of Return (IRR) describes the percentage of profit generated by the project, Calculation of Internal Rate of Return (IRR) using Trial and Error, calculation to find the amount of IRR will be tried using a discount rate of $22 \%$ and $23 \%$ to get accuracy in the calculation on what level is the NPV for this planned reception facility for the Tanjung Perak Branch of Surabaya.

To determine the amount of IRR can be calculated using the interpolation technique.

Viewed from the results of Perhitunga shows that IRR $=22.695 \%$ while the value of $\mathrm{COC}=14 \%$, means IRR> COC, so that this investment can be declared very feasible to implement.

\subsection{Average Rate Of Return (ARR) Method.}

This method measures how much the average profit rate obtained from an investment. The number used is after-tax profit compared to average investment. Furthermore, the results are compared with the required profit level.

ARR is a measure of the effectiveness of investment returns on investment costs with an accounting profit approach. The plan to construct a reception facility for the Tanjung Perak Branch of Surabaya is declared feasible if the ARR is greater than the level of the proposed profit (IRR), and conversely, if it is smaller then the production plan will be rejected.

From the table, the projection of profit/loss is known that the average after tax is $\mathrm{Rp}$.

$332,165,312$.

$A R R=$ Average profit after tax $X 100 \%$ Average investment

$\mathrm{ARR}=332.165,312 \times 100 \%$

$$
1,095,484,400=30.32 \%
$$

Judging from the results of the above calculation, it shows that the effectiveness measure of $\mathrm{ARR}$ investment results $=30.321 \%>\mathrm{IRR}=$ $22.305 \%$ so that this investment can be declared feasible to be implemented.

Pay Back Period (PP) Method 
This method is used to calculate how long the investment fund for the project development facility for the reception of Tanjung Perak Surabaya Port will return, the calculation also uses a cost of capital of $14 \%$ as a discount basis. Pelindo III Tanjung Perak Branch Surabaya expects that the investment fund can be returned when the reception facility management operates within a period of time in accordance with the 10-year longterm plan.

From the calculation, the calculation results are obtained as shown in the table as follows:

$$
\begin{aligned}
& \mathrm{PP}=8 \text { years } \\
& \mathrm{PP}=(811,203,058) \times 12 \\
& 1,095,484,400 \\
& =8.886 \approx 9 \text { months } \\
& \mathrm{PP}=0.886 \times 30 \\
& =25.98 \text { days } \approx 26 \text { days }
\end{aligned}
$$

The cumulative present value calculation illustrates that the initial investment construction project for the reception of Tanjung Perak Branch in Surabaya is Rp. $1,095,484,400.00$ will be closed after the reception facility of Tanjung Perak Branch Port Surabaya runs for 8 years 9 months 26 days.

\section{CONCLUSIONS.}

From the research on the assessment of the feasibility and construction of Reception Facility, the Tanjung Perak Branch Port of Surabaya concluded as follows:

a. Legal aspects

Judging from the regulation of Government Regulation Number 21 of 2010 concerning the protection of the Maritime Environment. Chapter IV Article 17 (1) each port that is operated must fulfill the requirements to prevent pollution from sources at activities in the port, including special terminals so that it is very possible that the construction project of the Surabaya Tanjung Perak Branch Port Reception Facility will be carried out.

\section{b. Market Aspects}

Judging from the increase in ship arrival data per year and forecasting the arrival of ships using Minitab, the average yield is 846 per year. from these results, it is very feasible to develop the Reception Facility of the Surabaya Tanjung Perak Branch Port.

C. Technical aspects

Judging from the construction location data, the Reception Facility of Tanjung Perak Branch Port in Surabaya, the initial investment plan and it's completeness facilities so that the plan to develop a proper Reception Facility is implemented.

\section{d. Financial aspects}

From the calculation of the feasibility of financial aspects are as follows:

1) Net Present Value (NPV) is greater than zero or exactly Rp. 431.257.167, - for 10 years the projection means that in terms of the financial aspects of the construction project the Reception Facility of the Tanjung Perak Branch Port of Surabaya is feasible.

2) The Profitability Index (PI) obtained from the calculation is 1.393667798 which means $\mathrm{Pl}>1$, so the planned construction project for the Reception Facility of Surabaya Tanjung Perak Branch Port is feasible to continue.

3) Internal Rate of Return (IRR) obtained from the calculation of $22.305 \%$, which means IRR $>\mathrm{COC}=14 \%$, then the planned construction project of the Reception Facility of Tanjung Perak Branch Port in Surabaya is feasible to continue.

4) Average Rate Of Return (ARR) obtained is $30.32 \%$, which means that the ARR is greater than the IRR, so the planned construction project of the Reception Facility of Tanjung Perak Branch of Surabaya is feasible to continue. 
5) The Payback Period (PP) obtained is 8 years 9 months 26 days investment funds for the construction of the Reception Facility of Tanjung Perak Branch Port in Surabaya will be faster than the time set so that the financial aspects are feasible to be implemented.

In addition to the above conclusions, there are suggestions to the leaders and officials of PT. Pelindo III related to this problem as follows:

a. Judging from the various aspects examined by the possibility of carrying out the construction of the Reception Facility at the Tanjung Perak Branch of Surabaya, it will bring positive benefits to both PT. Pelindo III and fishermen are generally among others to improve welfare by reducing vessel waste. b. In order for the investment assessment of the construction of the Surabaya Tanjung Perak Branch Reception Facility to obtain better results, it is necessary to improve the analysis of each aspect of the feasibility study. And also other supporting aspects that have not been analyzed in this study should also be considered.

\section{BIBLIOGRAPHY}

Gurning, Saut, (2001) Perencanaan Prototipe Instalasi Penampung Limbah dan Buangan Kapal, Laporan Penelitian SPP/DPP, Nopember 2001, Surabaya.

Husnan, S dan Suwarsono, (1992) Studi Kelayakan Proyek, edisi kedua, UPP AMP YKPN, Yogyakarta.

Husnan, S dan Suwarsono, (1994) Studi Kelayakan Proyek, edisi ketiga, UPP AMP YKPN, Yogyakarta.

Priyambodo, Danis, (2007) Analisa Kelayakan Pembangunan Bengkel Navigasi Elektronika Di
Fasharkan Lantamal III Jakarta, Laporan Penulisan tugas akhir, STTAL

Pujawan, I Nyoman (2004) Ekonomi Teknik, edisi pertama, cetakan ketiga, Guna Widya, Surabaya.

Rohman, Fatchur (2006) Studi Kelayakan Pembangunan Rumah Susun Perwira (Tipe 54) Di Daerah Basis TNI Angkatan Laut Koarmatim Ujung Surabaya, Laporan Penulisan tugas akhir, STTAL.

Rozaq, A, (2006) Studi Kelayakan Proyek Pembangunan Graving Dock di Koarmatim Ujung Surabaya, Laporan Penulisan tugas akhir, STTAL.

Siagian, Ferdinand H, (2006) Studi Kelayakan Senjata SS2 di Divisi Senjata PT. Pindad (Persero), Laporan Penulisan tugas akhir, STTAL.

Suratman, (2006) Studi Kelayakan Proyek Teknik dan Prosedur Penyusunan Laporan, edisi pertama, J \& J Learning, Yogyakarta. 